\title{
Age-Related Changes of Some Chemical Components in the Leaves of Oriental Beech (Fagus orientalis Lipsky.)
}

\author{
Nezahat Turfan ${ }^{1 *}$, Sezgin Ayan², Esra Nurten Yer², Halil Barış Özel ${ }^{3}$
}

(1) Kastamonu University, Faculty of Science and Literature, Biology Department, Kuzeykent Campus, TR-37150 Kastamonu, Turkey; (2) Kastamonu University, Faculty of Forestry, Silviculture Department, Kuzeykent Campus, TR-37100 Kuzeykent, Kastamonu, Turkey; (3) University of Bartin, Faculty of Forestry, Silviculture Department, TR-74100 Bartn, Turkey

* Correspondence: e-mail: nturfan@kastamonu.edu.tr

\begin{abstract}
Citation: TURFAN N, AYAN S, YER EN, ÖZEL HB 2019 Age-Related Changes of Some Chemical Components in the Leaves of Oriental Beech (Fagus orientalis Lipsky.). South-east Eur for 10 (2): 117-124. DOI: https://doi.org/10.15177/seefor.19-15 Received: 26 Feb 2019; Revised: 25 Apr 2019, 11 Jul 2019; Accepted: 20 Aug 2019; Published online: 4 Nov 2019
\end{abstract}

\begin{abstract}
Background and Purpose: This study presents the analysis of photosynthetic pigments, proline, total soluble protein, total amino acids, glucose, sucrose, total soluble sugars, total amount of phenolic compounds and flavonoids, malondialdehyde (MDA) and hydrogen peroxide $\left(\mathrm{H}_{2} \mathrm{O}_{2}\right)$ concentration in the leaf samples collected from oriental beech trees, which are naturally spread in Kastamonu Province, Turkey, with differing ages, enzyme activities of ascorbate peroxidase (APX), catalase (CAT) and superoxide dismutase (SOD).

Material and Methods: The research was carried out on oriental beech trees (Fagus orientalis L.) of different ages located at $1300 \mathrm{~m}$ high elevation in Ahlat Village of Kastamonu Province, Turkey. Oriental beech trees of different ages $(\geq 25, \geq 50$, $\geq 100, \geq 200$ and $\geq 600$ years-old) constituted the material of this study. In leaf samples taken from trees of different ages, photosynthetic pigments (chlorophyll $a$, chlorophyll $b$, total chlorophyll and carotenoid), proline, total soluble protein, total amino acid, glucose, sucrose, total soluble sugars, the amount of total phenolic compounds and flavonoids, $\mathrm{MDA}, \mathrm{H}_{2} \mathrm{O}_{2}$ concentration, enzyme activities of APX, CAT and SOD, as well as the relationship between the total content of $\mathrm{C}, \mathrm{N}$ and $\mathrm{H}$ elements and the tree ages were studied.

Results: As a result of the research conducted, significant differences were determined in terms of chlorophyll, total phenolic compound, flavonoid, glucose, amounts of sucrose, nitrogenous compounds, proline, total soluble protein, MDA, $\mathrm{H}_{2} \mathrm{O}_{2}$ concentrations, and the activities of APX, CAT and SOD in the leaves of oriental beech trees with differing ages. The highest content of chlorophyll $a$ was found to be in the youngest age group of $\geq 25$ years. Total chlorophyll is low in young trees and high in middle-aged, old and very old trees. According to the results obtained, it was concluded that the MDA and $\mathrm{H}_{2} \mathrm{O}_{2}$ concentrations in the trees did not vary depending on the age of trees only, but also on the genotype, environmental conditions and metabolic activities. It was concluded that the fact that the total chlorophyll, phenolic compounds and sucrose content in oriental beech trees are high and that MDA content is low could have an influence on the long life of $\geq 600$ years-old oriental beech trees.

Conclusions: The activity of photosynthesis is related to leaf characteristics more than the age of trees.
\end{abstract}

Keywords: Tree physiology, Oriental beech, Chemical content, Tree age, Enzyme activities.

\section{INTRODUCTION}

In studies analysing the growth and development of trees, the balance between photosynthesis/respiratory rate [1], coordination between the above-ground and underground organs [2], metabolic processes [3] and the changes in environmental factors were found to be affecting the growth and development of trees $[4,5]$. Approximately, $1 / 3$ of daily photosynthesis gain of young trees was used for respiration [6]; this consumption increased in old trees even more with the change in the ratio of photosynthetic tissue/nonphotosynthetic tissue [7-9]; deficiency in nutrient distribution and the respiratory activities were the determining factors that reflect the aging phenology; and when the tissues and organs completed their maturation period, the respiration slowed down, while the senescence accelerated [10]. The 
effect of irreversible deterioration, which started in the physical and chemical structure of chloroplasts, in the stimulation of senescence was very high. The accumulation of toxic substances in the tissues and cells such as reactive oxygen (ROS), malondialdehyde (MDA), and ketones increased and apoptotic deaths started afterwards [11]. The prediction of biological life of a tree, and thus the future of a forest, depends on the determination of its economic life and cause-effect relationships. Hence, many researchers reported that establishing the ecological characteristics of the forests and the individual growth and increment relationships of all the species forming those forests was an important step in forest planning $[12,13]$.

Oriental beech (Fagus orientalis Lipsky.) is an important species covering a total of $1,751,484$ ha of spreading area including 1,373,245 ha of productive high forest lands and 378,239 ha of unproductive high forest lands in Turkey, and it takes the third place in terms of country-wide growing stock after Turkish pine (Pinus brutia Ten.) and Anatolian black pine (Pinus nigra Arnold) [14]. However, forest lands around the world have been decreasing due to silvicultural interventions, which were not conducted according to abiotic and biotic stress factors and techniques, and which is why the productivity in the forests of oriental beech, which is one of our fundamental tree species, has also been decreasing [15]. The fact that forests in Turkey have rich biological and genetic diversity depending on different habitat conditions is directly effective in determining the techniques to be applied in the rejuvenation and maintenance works to be carried out, and in the success of those works. For this reason, in forest lands, where silvicultural interventions are carried out, the growing conditions of oriental beech trees, stand establishment characteristics (pure or mixed stands, closure, density, etc.) and particularly the monitoring of age-related growth and development relationships have significant importance $[16,17]$. In this study, the age-related changes in organic compounds such as photosynthetic metabolism, which takes part in growing and development processes of oriental beech trees of different ages, protein, proline, soluble sugars, damages occurring in cellular membranes and their effects on chemical content, antioxidant enzymes, total phenolic compounds and flavonoids were presented.

\section{MATERIAL AND METHODS}

\section{Material}

Oriental beech trees (Fagus orientalis L.) of different ages ( $\geq 25, \geq 50, \geq 100, \geq 200$ and $\geq 600$ years-old) located at $1300 \mathrm{~m}$ high elevation (223'50" N, 3346'50" E) (Figure 1) in Ahlat Village of Kastamonu Province constituted the material of this study. The age determination of the trees in the sampling area was performed by counting the annual rings on the increment corer taken by an increment borer from 3 trees in each agegroup at the breast height $\left(\mathrm{d}_{1.30} \mathrm{~m}\right)$. While determining the age of the tree with increment borer, attention was paid to ensure that the increment corer was in two perpendicular directions in order to prevent the error that may occur in measuring the annual ring and eccentric growth. The fresh leaves under the canopy of the trees belonging to each age group in the sampling area were collected from each direction of the tree in the second half of July [18].

\section{Methods}

In leaf samples taken from trees of different ages, photosynthetic pigments (chlorophyll $a$, chlorophyll $b$, total chlorophyll and carotenoid), proline, total soluble protein, total amino acid, glucose, sucrose, total soluble sugars, the amount of total phenolic compounds and flavonoids, malondialdehyde (MDA), hydrogen peroxide $\left(\mathrm{H}_{2} \mathrm{O}_{2}\right)$ concentration, enzyme activities of ascorbate peroxidase (APX), catalase (CAT) and superoxide dismutase (SOD) as well as the relationship between the total content of $\mathrm{C}, \mathrm{N}$ and $\mathrm{H}$ elements and the tree ages were studied.

The $\mathrm{C}, \mathrm{N}$ and $\mathrm{H}$ content of the leaf samples was measured by the XRF device of SPECTRO brand and XEPOS model available at Kastamonu University Central Research Laboratory.

In order to determine the chlorophyll content, $0.5 \mathrm{~g}$ of fresh leaf tissue was thoroughly crushed inside liquid nitrogen and was homogenized by adding $5 \mathrm{ml}$ of $80 \%$ acetone solution at $4^{\circ} \mathrm{C}[19,20]$ The homogenate was centrifuged at $3000 \mathrm{rpm}$ for 10 minutes and the spectrophotometric reading of the supernatants taken were performed in triplicate at the values of $450,645,663 \mathrm{~nm}$. In determining the total chlorophyll content, the Arnon equation [21] was used, whilst the carotenoid content was determined based on the

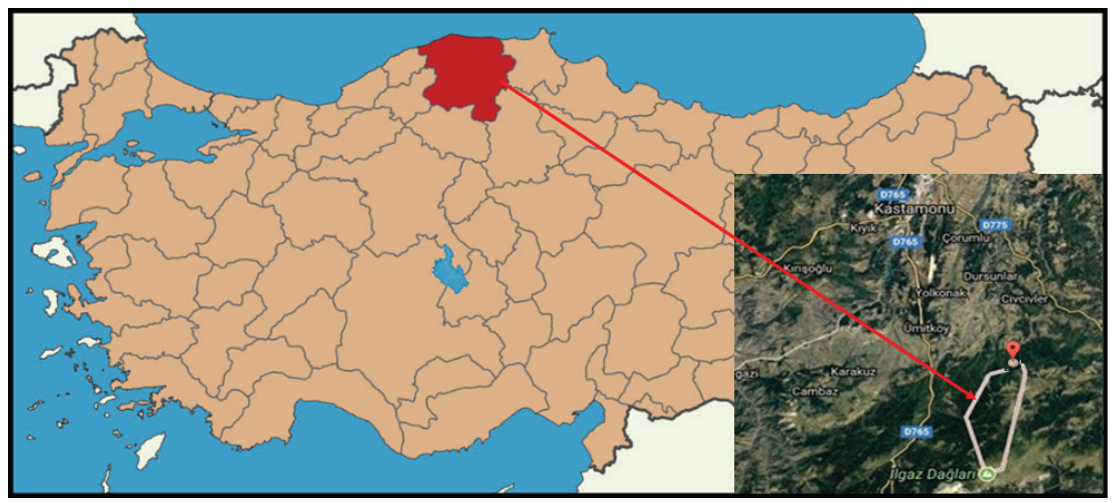

FIGURE 1. Research area 
Jaspars formula [22]. The proline content in leaf samples was determined according to the Bates method [23], whilst the protein content was determined according to the Bradford method [24], MDA [25] and $\mathrm{H}_{2} \mathrm{O}_{2}$ extraction [26].

Total carbohydrate quantitation was carried out by using the Anthrone method [27]; $1 \mathrm{~g}$ of powder sample was homogenized in $80 \%$ ethanol. Absorbance of some of the homogenate was measured at $630 \mathrm{~nm}$ by a spectrophotometer, and glucose and total starch quantitation was performed. The remaining filtrate was extracted using $52 \%$ perchloric acid and its absorbance values were measured at $620 \mathrm{~nm}$ wavelength by a spectrophotometer, and were then used for sucrose and total soluble carbohydrate measurement. Total phenolic analysis was performed according to the spectrophotometric Folin-Ciocalteu method [28]. Total flavonoid quantitation was carried out spectrophotometrically (Shimadzu UV-260) [29].

While determining the enzyme activities of fresh leaf samples, $0.5 \mathrm{~g}$ of fresh leaf sample was crushed inside liquid nitrogen and then homogenized with $5 \mathrm{ml}$ of $50 \mathrm{mM}(\mathrm{pH}=7.6)$ $\mathrm{KH}_{2} \mathrm{PO}_{4}(\mathrm{pH}=7)$ buffered solution containing $0.1 \mathrm{mMNa}$-EDTA. The homogenized samples were centrifuged at $15000 \mathrm{~g}$ and $4^{\circ} \mathrm{C}$ for 15 minutes. Enzyme activities were measured in this supernatant. APX was determined spectrophotometrically according to the method applied by Nakano \& Asada [30] by measuring the oxidation rate of ascorbate at 290 $\mathrm{nm}(\mathrm{E}=2.8 \mathrm{mM} \mathrm{cm}-1)$, while CAT activity was determined spectrophotometrically according to Bergmeyer [31], and SOD enzyme activity according to the method applied by Cakmak [32].

\section{Statistical Analysis}

Whether each parameter of the chemical compounds detected on the leaves differed significantly by age or not was presented through the F-test of the Analysis of Variance (ANOVA) using the SPSS program (Version 11). According to the ANOVA results $(P \leq 0.05)$, to determine statistically significant differences between means Tukey test as a multiple range test was applied.

\section{RESULTS}

\section{Changes in the Amount of Photosynthetic Pigment, Total Phenolic Compounds and Flavonoids}

Changes in the amount of photosynthetic pigments, total phenolic compounds and flavonoids in the oriental beech leaves are given in Table 1. According to the variance analysis results, the amounts of chlorophyll $a, b$, chlorophyll $a / b$, total chlorophyll, total phenolic compound and flavonoids showed significant differences depending on tree age except total carotenoids (Table 1).

The pigment content changed significantly according to age groups of the trees $(p<0.05)$. The highest content of chlorophyll $a$ in eastern beech trees was detected in the youngest age group of $\geq 25$ years-old trees $(0.159 \mathrm{mg})$, while the content of chlorophyll $b$ was found in older trees. The lowest content of chlorophyll $b$ was found to be $0.128 \mathrm{mg}$ in $\geq 25$ years-old trees (Table 1 ).

The total chlorophyll content varied between 0.287 and $0.408 \mathrm{mg}$. While the youngest $(\geq 25)$ oriental beech tree had the lowest chlorophyll content of $0.287 \mathrm{mg}$, the oldest $(\geq 600)$ oriental beech tree within the research material had the highest chlorophyll content of $0.408 \mathrm{mg}$. In terms of chlorophyll $a / b, \geq 25$ years-old age group was found to have the highest chlorophyll $a / b$ value, while the $\geq 600$ years-old group had the lowest. Chlorophyll $a / b$ ratio of the youngest group was found to be approximately 2.3 times higher than the oldest group.

No significant change was detected between age groups of trees in terms of carotenoid content. In terms of total phenolic compounds content, the highest value was obtained from a tree older than 600 years, while in terms of flavonoids content, the highest value was obtained from a tree older than 200 years. The lowest total phenolic compound content was recorded in a tree older than 200 years, and the lowest flavonoid content was recorded in a beech tree older than 25 years (Table 1).

Changes in the Amount of Glucose, Sucrose, Total Soluble Carbohydrate and Starch

While significant differences were detected in the glucose and sucrose contents of beech trees of different ages, no significant change was determined in total soluble carbohydrate and starch contents. In addition to this, the highest glucose, total soluble carbohydrate and starch contents were detected in beech trees older than 200 years, while the highest sucrose content was recorded in trees older than 600 years (Table 2).

\section{N, C and $\mathrm{H}$ Content Changes}

In oriental beech tree leaves, the $\mathrm{N}$ content was found to be the highest in trees older than 200 and 100 years, and

TABLE 1. Results of variance analysis and Tukey test according to age groups for the amount of photosynthetic pigments (chlorophyll a, chlorophyll b, total chlorophyll and carotenoid), total phenolic compounds and flavonoids.

\begin{tabular}{cccccccc}
\hline Age group & $\begin{array}{c}\text { Chlorophyll } a \\
\left(\mathrm{mg} \cdot \mathrm{g}^{-1}\right)\end{array}$ & $\begin{array}{c}\text { Chlorophyll } \boldsymbol{b} \\
\left(\mathrm{mg} \cdot \mathrm{g}^{-1}\right)\end{array}$ & $\begin{array}{c}\text { Total } \\
\text { Chlorophyll } \\
\left(\mathrm{mg} \cdot \mathrm{g}^{-1}\right)\end{array}$ & $\begin{array}{c}\text { Chlorophyll } \\
a / b \\
\left(\mathrm{mg} \cdot \mathrm{g}^{-1}\right)\end{array}$ & $\begin{array}{c}\text { Total } \\
\text { Carotenoid } \\
\left(\mathrm{mg} \cdot \mathrm{g}^{-1}\right)\end{array}$ & $\begin{array}{c}\text { Total Phenolic } \\
\text { Compound } \\
\left(\mu \mathrm{g} \cdot \mathrm{g}^{-1}\right)\end{array}$ & $\begin{array}{c}\text { Flavonoid } \\
\left(\mu \mathrm{g} \cdot \mathrm{g}^{-1}\right)\end{array}$ \\
\hline$\geq 25$ & $0.159 \pm 0.002 \mathrm{~b}$ & $0.128 \pm 0.020 \mathrm{a}$ & $0.287 \pm 0.02 \mathrm{a}$ & $1.301 \pm 0.214 \mathrm{a}$ & $9.41 \pm 0.014 \mathrm{a}$ & $17.16 \pm 0.18 \mathrm{~b}$ & $8.89 \pm 0.19 \mathrm{a}$ \\
$\geq 50$ & $0.147 \pm 0.002 \mathrm{a}$ & $0.239 \pm 0.020 \mathrm{~b}$ & $0.386 \pm 0.02 \mathrm{~b}$ & $0.626 \pm 0.063 \mathrm{ab}$ & $9.48 \pm 0.03 \mathrm{a}$ & $16.13 \pm 0.11 \mathrm{ab}$ & $9.07 \pm 0.09 \mathrm{~b}$ \\
$\geq 100$ & $0.147 \pm 0.001 \mathrm{a}$ & $0.260 \pm 0.002 \mathrm{c}$ & $0.406 \pm 0.01 \mathrm{c}$ & $0.566 \pm 0.003 \mathrm{~b}$ & $9.42 \pm 0.03 \mathrm{a}$ & $16.23 \pm 0.12 \mathrm{ab}$ & $9.12 \pm 0.10 \mathrm{~b}$ \\
$\geq 200$ & $0.148 \pm 0.001 \mathrm{a}$ & $0.257 \pm 0.002 \mathrm{c}$ & $0.404 \pm 0.01 \mathrm{c}$ & $0.575 \pm 0.001 \mathrm{~b}$ & $9.44 \pm 0.03 \mathrm{a}$ & $15.16 \pm 0.13 \mathrm{a}$ & $9.21 \pm 0.12 \mathrm{~b}$ \\
$\geq 600$ & $0.149 \pm 0.001 \mathrm{a}$ & $0.259 \pm 0.001 \mathrm{c}$ & $0.408 \pm 0.01 \mathrm{c}$ & $0.573 \pm 0.002 \mathrm{~b}$ & $9.42 \pm 0.04 \mathrm{a}$ & $17.75 \pm 0.16 \mathrm{~b}$ & $8.96 \pm 0.05 \mathrm{a}$ \\
F value & 17.216 & 21.488 & 20.691 & 10.392 & 1.018 & 5027.95 & 118.37 \\
Sig. Lev. & 0.000 & 0.000 & 0.000 & 0.001 & 0.443 & 0.000 & 0.000 \\
\hline
\end{tabular}


the lowest in trees older than 50 years. Hydrogen content is the highest in beech trees older than 200 and 100 years and the lowest in young beech trees older than 25 years (Table 3).

Changes in Proline, Total Soluble Protein, Total Amino Acid and MDA and H2O2 Concentration

Age-related change of nitrogenous compounds such as proline, total soluble protein, total amino acid and nitrogen (\%) in oriental beech trees was found statistically significant. Also, MDA and $\mathrm{H}_{2} \mathrm{O}_{2}$ concentrations demonstrated significant age-related differences. $\mathrm{H}_{2} \mathrm{O}_{2}$ concentration varied between $80.88 \mu \mathrm{mol}$ and $161.53 \mu \mathrm{mol}$ (Table 4).

\section{Antioxidant activity changes}

APX, CAT and SOD activities were affected by tree age at a significant level. The APX activity was found to be the lowest in a tree older than 600 years. CAT activity was $72.96 \%$ higher in trees older than 200 years compared to $\geq 600$ years-old trees and $13.54 \%$ lower in trees older than 100 years. On the other hand, the SOD activity was found to be higher in $\geq 50$ and $\geq 600$ years-old beech trees (Table 5 ).

TABLE 2. Results of variance analysis and Tukey test according to age groups for glucose, sucrose, total soluble carbohydrate and starch contents.

\begin{tabular}{ccccc}
$\begin{array}{c}\text { Age } \\
\text { group }\end{array}$ & $\begin{array}{c}\text { Glucose } \\
\left(\mathrm{mg} \cdot \mathrm{g}^{-1}\right)\end{array}$ & $\begin{array}{c}\text { Sucrose } \\
\left(\mathrm{mg} \cdot \mathrm{g}^{-1}\right)\end{array}$ & $\begin{array}{c}\text { Total Soluble Carbohydrate } \\
\left(\mathrm{mg} \cdot \mathrm{g}^{-1}\right)\end{array}$ & $\begin{array}{c}\text { Starch } \\
\left(\mathrm{mg} \cdot \mathrm{g}^{-1}\right)\end{array}$ \\
$\geq 25$ & $70.47 \pm 0.02 \mathrm{a}$ & $67.44 \pm 0.02 \mathrm{a}$ & $53.55 \pm 0.28 \mathrm{a}$ & $49.99 \pm 0.02 \mathrm{a}$ \\
$\geq 50$ & $71.62 \pm 0.02 \mathrm{a}$ & $66.89 \pm 0.04 \mathrm{a}$ & $53.77 \pm 0.11 \mathrm{a}$ & $50.19 \pm 0.02 \mathrm{a}$ \\
$\geq 100$ & $71.17 \pm 0.03 \mathrm{a}$ & $68.41 \pm 0.04 \mathrm{~b}$ & $54.63 \pm 0.22 \mathrm{a}$ & $50.99 \pm 0.03 \mathrm{a}$ \\
$\geq 200$ & $72.06 \pm 0.03 \mathrm{~b}$ & $67.77 \pm 0.05 \mathrm{a}$ & $55.34 \pm 0.23 \mathrm{a}$ & $51.65 \pm 0.03 \mathrm{a}$ \\
$\geq 600$ & $71.46 \pm 0.03 \mathrm{a}$ & $68.60 \pm 0.11 \mathrm{~b}$ & $54.36 \pm 0.17 \mathrm{a}$ & $50.73 \pm 0.03 \mathrm{a}$ \\
F Value & 817.91 & 156.82 & 1160.51 & 1160.51 \\
Sig. Lev. & 0.000 & 0.000 & 0.000 & 0.000 \\
\hline
\end{tabular}

TABLE 3. Results of variance analysis and Tukey test according to age groups for $\mathrm{N}, \mathrm{C}$ and $\mathrm{H}$ content changes.

\begin{tabular}{cccc}
\hline Age Group & N\% & C\% & H\% \\
\hline 25 & $0.62 \pm 0.0002 \mathrm{c}$ & $14.91 \pm 0.0006 \mathrm{~b}$ & $1.95 \pm 0.0006 \mathrm{a}$ \\
$\geq 50$ & $0.57 \pm 0.0004 \mathrm{a}$ & $14.79 \pm 0.0004 \mathrm{a}$ & $1.98 \pm 0.0004 \mathrm{~b}$ \\
$\geq 100$ & $0.64 \pm 0.0006 \mathrm{~d}$ & $15.00 \pm 0.0002 \mathrm{~d}$ & $1.99 \pm 0.0004 \mathrm{~b}$ \\
$\geq 200$ & $0.68 \pm 0.0004 \mathrm{e}$ & $15.23 \pm 0.0004 \mathrm{e}$ & $2.04 \pm 0.0004 \mathrm{c}$ \\
$\geq 600$ & $0.61 \pm 0.0006 \mathrm{~b}$ & $14.92 \pm 0.0004 \mathrm{c}$ & $1.98 \pm 0.0004 \mathrm{~b}$ \\
F Value & 8241.50 & 165248.99 & 5957.22 \\
Sig. Lev. & 0.000 & 0.000 & 0.000 \\
\hline
\end{tabular}

TABLE 4. Results of variance analysis and Tukey test according to age groups for proline, total soluble protein, total amino acid, MDA and $\mathrm{H}_{2} \mathrm{O}_{2}$ contents.

\begin{tabular}{|c|c|c|c|c|c|}
\hline $\begin{array}{l}\text { Age } \\
\text { group }\end{array}$ & $\begin{array}{c}\text { Proline } \\
\left(\mu \mathrm{mol} \cdot \mathrm{g}^{-1}\right)\end{array}$ & $\begin{array}{l}\text { Total Soluble Protein } \\
\left(\mathrm{mg} \cdot \mathrm{g}^{-1}\right)\end{array}$ & $\begin{array}{c}\text { Total Amino Acid } \\
\left(\mu \mathrm{g} \cdot \mathrm{g}^{-1}\right)\end{array}$ & $\begin{array}{c}\text { MDA } \\
\left(\mu \mathrm{mol} \cdot \mathrm{g}^{-1}\right)\end{array}$ & $\begin{array}{c}\mathbf{H}_{2} \mathbf{O}_{2} \\
\left(\mu \mathrm{mol} \cdot \mathrm{g}^{-1}\right)\end{array}$ \\
\hline$\geq 25$ & $56.22 \pm 0.02 c$ & $11.52 \pm 0.10 c$ & $29.81 \pm 0.05 c$ & $15.97 \pm 0.13 e$ & $80.77 \pm 0.19 a$ \\
\hline$\geq 50$ & $50.69 \pm 0.20 a$ & $8.41 \pm 0.16 a$ & $20.69 \pm 0.03 a$ & $6.86 \pm 0.20 \mathrm{a}$ & $92.58 \pm 0.24 b$ \\
\hline$\geq 100$ & $60.82 \pm 0.04 d$ & $15.12 \pm 0.06 d$ & $32.38 \pm 0.10 d$ & $9.84 \pm 0.16 c$ & $131.58 \pm 0.19 d$ \\
\hline$\geq 200$ & $69.32 \pm 0.11 \mathrm{e}$ & $21.18 \pm 0.10 \mathrm{e}$ & $40.22 \pm 0.05 e$ & $12.05 \pm 0.16 d$ & $161.53 \pm 0.22 \mathrm{e}$ \\
\hline$\geq 600$ & $53.86 \pm 0.03 b$ & $10.16 \pm 0.10 b$ & $27.03 \pm 0.02 b$ & $7.78 \pm 0.15 b$ & $110.86 \pm 0.34 c$ \\
\hline F Value & 52.371 & 2338.756 & 8257.961 & 53675.291 & 34087.214 \\
\hline Sig. Lev. & 0.000 & 0.000 & 0.000 & 0.000 & 0.000 \\
\hline
\end{tabular}


TABLE 5. Results of variance analysis and Tukey test according to age groups for the amounts of APX, CAT and SOD activities.

\begin{tabular}{cccc}
\hline Age Group & APX & CAT & SOD \\
$\geq 25$ & $0.271 \pm 0.001 \mathrm{~b}$ & $0.164 \pm 0.002 \mathrm{c}$ & $48.49 \pm 0.23 \mathrm{~b}$ \\
$\geq 50$ & $0.284 \pm 0.001 \mathrm{~d}$ & $0.168 \pm 0.001 \mathrm{c}$ & $56.53 \pm 0.08 \mathrm{~d}$ \\
$\geq 100$ & $0.289 \pm 0.001 \mathrm{e}$ & $0.133 \pm 0.002 \mathrm{a}$ & $51.26 \pm 0.13 \mathrm{c}$ \\
$\geq 200$ & $0.276 \pm 0.001 \mathrm{c}$ & $0.266 \pm 0.002 \mathrm{~d}$ & $39.28 \pm 0.19 \mathrm{a}$ \\
$\geq 600$ & $0.258 \pm 0.002 \mathrm{a}$ & $0.154 \pm 0.003 \mathrm{~b}$ & $55.5 \pm 0.19 \mathrm{~d}$ \\
F Value & 26.531 & 2057.27 & 4358.07 \\
Sig. Lev. & 0.000 & 0.000 & 0.000 \\
\hline
\end{tabular}

\section{DISCUSSION AND CONCLUSION}

Chlorophyll $a$, chlorophyll $b$, total chlorophyll and carotenoids are photoreceptors functioning in photosynthesis. While chlorophyll $a$ molecule plays an important role in the transmission of electrons, chlorophyll $a$ and carotenoids are also effective in protecting the chloroplast membranes from getting photo oxidative damage as well as absorbing the light [33]. In the study, the highest chlorophyll $a$ and the lowest chlorophyll $b$ content were determined in the youngest oriental beech tree. Total chlorophyll was low in young trees, while it was high in middle-aged, old and very old trees. Total carotenoid did not demonstrate a significant change between trees (Table 1).

These results were in accordance with the results of the study conducted on the age-related changes in photosynthetic activity and the pigment content. The photosynthetic pigment content in herbal tissues varied according to parameters such as leaf anatomy, morphology and growth status, age, height and volume of the tree as well as light, drought and soil characteristics $[34,35]$. The fact that the leaves of the tree older than 25 years have high chlorophyll $b$ and total chlorophyll content and have low chlorophyll $a$ content was associated with light conditions.

In fact, chlorophyll $b$ content was high in plants growing in low light conditions or in shaded areas [36], while chlorophyll $a$ content was decreasing; chlorophyll $a$ and $b$ molecules transformed to each other depending on the light conditions. $\mathrm{H}_{2} \mathrm{O}_{2}$ ratio increased in case the chlorophyll $b$ content was high [37]. Contents of chlorophyll $b$ and $\mathrm{H}_{2} \mathrm{O}_{2}$ in aged trees also confirmed this result (Table 1,4$)$. Since carotenoids, which protect the chloroplast membranes with their antioxidant characteristics, were more stable compounds compared to the chlorophyll molecule, they did not show a significant change among the trees [33].

Carbon is the most abundant element found in all living systems. Researchers reported that $45 \%$ of the plants' dry weight was made of carbon, and that the plants obtained carbon through photosynthesis and respiratory reactions [6]. Apart from photosynthesis-fixed carbon being added in the structure of primary and secondary metabolites, it is also stored in pools in order to be used in the future [38]. $\mathrm{C}$ accumulation in plant tissues is closely related to the balance between photosynthesis and respiratory rate [39]. The $\mathrm{C}$ content in beech trees of different ages did not show significant changes (Table 3). Glucose, total carbohydrate and starch contents are higher in trees older than 200 years, while sucrose content is higher in trees older than 600 years. Contrastingly, glucose, sucrose, total soluble carbohydrate and starch contents have at the lowest levels in the youngest beech trees $(\geq 25)$ (Table 2). The fact that total carbon, total soluble carbohydrate and starch contents in beech trees of different age groups do not change significantly shows that the photosynthesis/respiration rate is equal during the day and that there is no problem in the distribution of assimilates and metabolites in trees [6].

Morphology, functions and biochemistry of cells, tissues and organs of the plants change during their developmental stages such as seedlings, juvenile, adult and senile stages [40]. Increase in tissue and organ deformation along with aging stimulates the accumulation of lipid peroxidation products such as MDA and ketonic compounds, and the ROS derivatives such as $\mathrm{H}_{2} \mathrm{O}_{2}$ and SOD anions in plant cells and tissues [41]. However, the plants can destroy these compounds, which reduce the cellular activity and stimulate oxidative stress in plants, by means of APX, CAT, peroxidases and enzymatic compounds such as SOD, carotenoids, phenolic compounds and non-enzymatic compounds such as proline [42]. Within the scope of this study, MDA concentration was found to be the highest in the youngest beech tree, whereas $\mathrm{H}_{2} \mathrm{O}_{2}$ concentration was low in young trees and high in middle-aged and mature trees (Table 4). Especially, the $\geq 100$ years-old oriental beech tree has the highest $\mathrm{H}_{2} \mathrm{O}_{2}$ content. According to the results obtained, it was concluded that MDA and $\mathrm{H}_{2} \mathrm{O}_{2}$ concentrations of trees vary depending on genotype, environmental conditions, tree age and metabolic activities (Table 4). In the studies conducted, it was stated that MDA and $\mathrm{H}_{2} \mathrm{O}_{2}$ concentrations in plants increased during processes such as tissue and organ development, tracheal differentiation and senescence [43]. Deteriorations in the lipid structure and increase in the cell MDA and ROS derivatives were determined to be formed through leaf development [44], through the formation of tracheal elements in the leaf [45], and through aging of tissue and organs [46]. In this study, the changes in $\mathrm{H}_{2} \mathrm{O}_{2}$ concentration of oriental beech trees confirm this result. The fact that $\mathrm{H}_{2} \mathrm{O}_{2}$ content in trees older than 600 years decreases compared to trees older than 200 and 100 years was associated with the fact that young trees have larger leaf area compared to the old ones, and the fact that transmission bundle areas decrease with body deformations of the tree [45]. In addition, secondary cell walls activities in the old trees also work with $\mathrm{H}_{2} \mathrm{O}_{2}$ activity [46]. 
In this study, APX has the lowest activity in the oldest $(\geq 600)$ beech trees, while CAT has the lowest activity in beech trees older than 100 years. SOD has the lowest activity in beech trees older than 200 years. In spite of this, APX activity is the highest in beech trees older than 100 years, CAT is the highest in trees older than 200 years and SOD in trees older than 50 years (Table 4). Not many studies of age-related enzyme changes could be found in the literature. However, the fact that morphological, physiological and biochemical changes in the developmental stages of the tree, especially age-related senescence events, stimulate the membrane functions and structure as well as the ROS production necessitate the synthesis of antioxidant compounds $[10,11]$. As a matter of fact, high $\mathrm{H}_{2} \mathrm{O}_{2}$ damage in trees older than 200 years may be balanced with high CAT activities and with high APX activities in trees older than 200 years (Table 4) [47]. Both enzymes eliminate the impact of $\mathrm{H}_{2} \mathrm{O}_{2}$. In addition to this, high levels of SOD and APX activity in trees with low MDA content also refer to the inhibitory effects of these enzymes on lipid peroxidation [48].

Among the non-enzymatic compounds contributing in the elimination of ROS accumulation and lipid peroxidation damages, proline and total soluble proteins are particularly important [49]. In addition, phenolic compounds and flavonoids are also important non-enzymatic compounds affecting the growth and development of plants [50]. Besides, they play an important role in increasing tolerance to environmental changes through their functions such as cell wall activities, distribution of assimilates and osmotic regulation [51].

The highest proline, total soluble protein and total nitrogen contents of beech trees at different ages were detected in tree leaves older than 200 years. These compounds have the lowest values in beech trees older than 50 years (Table 5 ). The fact that proline and protein contents are the lowest in beech trees older than 50 and 600 years, where the nitrogen content is low, suggested that nitrogenous compounds were closely related to nitrogen available in tissues. The proline and protein contents in the tissues were related to the nitrogen pool [52].
As a matter of fact, this result arose due to the fact that the proline and protein values were the highest in oriental beech trees older than 200 years, which had also the highest $\mathrm{N}$ content. Furthermore, in a tree older than 100 years, where the total $N$ content is the second highest, the aforementioned compounds are also the second highest (Table 3 ). In addition to this, the high content of chlorophyll pigments in these trees also indicates the adaptation to source/pool balancing [53]. Moreover, the high nitrogen content in trees older than 100 and 200 years may be a physiological response to the increase in hydrolytic resistance of these trees [54]. $\mathrm{H}_{2} \mathrm{O}_{2}$-stimulated proline synthesis stimulated the wall resistance, thus increasing tolerance to stress in plants [55].

Phenolic compounds are secondary metabolite derivatives which are involved in physiological processes such as being the compounds of cell wall elements, regulating the wall elasticity and plasticity, and ensuring resistance to photoprotectant and pathogen attacks against the UV light [56]. The content of total phenolic compound is the highest in the oldest and youngest oriental beech trees, while it is the lowest in a tree older than 200 years. The flavonoid content did not demonstrate significant changes among the trees, but the highest flavonoid content was detected in a tree older than 200 years (Table 5). Total phenolic compounds and flavonoid values indicate that there are no significant changes to cause stress in the environment where the oriental beech trees grow [50].

Amino acid, proline, $\mathrm{H}$, glucose, sucrose and total soluble carbohydrate contents in trees older than 100 and 200 years indicate that the respiratory activities are high [57]. In trees older than 600 years, glucose and sucrose contents coincide with pigment values. This result indicates that photosynthetic activity is more associated with leaf characteristics rather than the tree age. Many researchers state that the photosynthetic activity of the leaf changes depending on the developmental status of the leaf, the leaf's position on the plant and its light-receiving capacity [53-58].

\section{REFERENCES}

1. KROMER S 1995 Respiration during photosynthesis. Ann Rev Plant Physiol Plant Mol Biol 46: 45-70. DOI: https://doi. org/10.1146/annurev.pp.46.060195.000401

2. PEICHL M, ARAIN MA 2006 Above and below ground ecosystem biomass and carbon pools in an age-sequence of temperate pine plantation forests. Ag Forest Meteorol 140: 51-63. DOI: https://doi.org/10.1016/i.agrformet.2006.08.004

3. BOND BJ 2000 Age-related changes in photosynthesis of woody plants. Trends Plant Sci 5 (8): 349-353. DOI: https://doi. org/10.1016/S1360-1385(00)01691-5

4. LOUIS J, MEYER S, MAUNOURY-DANGER F, FRESNEAU C, MEUDEC E, CEROVIC ZG 2009 Seasonally changes in optically assessed epidermal phenolic compounds and chlorophyll contents in leaves of sessile oak (Quercus petraea): towards signatures of phenological stage. Functional Plant Biology 36: 732-741. DOI: https://doi.org/10.1071/FP09010
5. KRESLAVSKI VD, LOS DA, ALLAKHVERDIEV SI, KUZNETSOV V 2012 Signalling role of reactive oxygen species in plants under stress. Russ J Plant Physiol 59: 141-154. DOI: https://doi. org/10.1146/annurev-arplant-042817-040322

6. DELUCIA EH, DRAKE JE, THOMAS RB, GONZALEZ-MELER M 2007 Forest carbon use efficiency: is respiration a constant fraction of gross primary production? Glob Change Biol 13:1157-1167. DOI: https://doi.org/10.1111/i.1365-2486.2007.01365.x

7. POETHIG R 2013 Vegetative phase change and shoot maturation in plants. Curr Top Dev Biol 105: 125-152. DOI: https://doi. org/10.1016/B978-0-12-396968-2.00005-1

8. LIM OP, NAM GH 2007 Aging and senescence of the leaf organ. J of Plant Biol 50 (3): 291-300. DOI: https://doi.org/10.1007/ BF03030657

9. RYAN MG, YODER BJ 1997 Hydraulic limits to tree height and tree growth. BioScience 47: 235-242. DOI: https://doi. org/10.2307/1313077 
10. CASWELL H, SALGUERO-GÓMEZ R 2013 Age, stage and senescence in plants. J Ecol 101: 585-595. DOI: https://doi. org/10.1111/1365-2745.12088

11. THOMAS H 2013 Senescence, ageing and death of the whole plant. New Phytol 197: 696-711. DOI: https://doi.org/10.1111/ nph.12047

12. BETTINGER P, CHUNG W 2004 The key literature of, and trends in, forest-level management planning in North America, 19502001. Int For Rev 6 (1): 40-50. DOI: https://doi.org/10.1505/ ifor.6.1.40.32061

13. BURKHART HE 1995 Modelling forest growth. Encyclopedia of Environmental Biology, 2: 535-543. DOI: https://doi. org/10.1007/978-90-481-3170-9

14. ANONYMOUS 2006 Forest presence. Ministry of Environment and Forestry, General Directorate of Forestry, Ankara, Turkey, $152 \mathrm{p}$

15. TUNCTANER K, OZEL HB 2008 Regeneration problems of oriental beech (Fagus orientalis Lipsky.) forests in Western Black Sea Region. Journal of Bartin Forestry Faculty 10 (13): 57-65

16. ÖZEL HB 2007 Stand structures and the factors affecting the success of group natural regeneration practices in Bartn and Devrek Oriental beech (Fagus orientalis Lipsky.) forests. PhD Thesis, Zonguldak Karaelmas Üniversitesi, Fen Bilimleri Enstitüsü, Bartın, Turkey, $272 \mathrm{p}$

17. ODABAŞI T, BOZKUS HF, CALISKAN A 2004 Silviculture Technique. Istanbul University, Faculty of Forestry, IU Publication Nu: 4459, FF Publication Nu: 475, Istanbul, Turkey, $314 \mathrm{p}$

18. SUMANGALA HP, ASWATH C, LAXMAN RH, NAMRATHA MR 2018 Evaluation of air pollution tolerance index (ATPI) of selected ornamental tree species of Bengaluru, India. Int J Pure App Biosci 6 (3): 366-373. DOI: http://dx.doi.org/10.18782/23207051.6382

19. LICHTENTHALER H, WELLBURN AR 1985 Determinations of total carotenoids and chlorophylls a and b of leaf extracts in different solvents. Biochem Soc T 11 (5): 591-592. DOI: https:// doi.org/10.1042/bst0110591

20. WITHAM, FH, DF BLAYDES, RM DEVLIN 1971 Experiments in plant physiology. Nostrand Reinhold Co., New York, USA, 245 p. URL: https://lib.ugent.be/catalog/rug01:001190680

21. ARNON DI 1949 Copper enzymes in isolated chloroplasts. Polyphenol oxidase in Beta vulgaris. Plant Physiol 24: 1-15. DOI: https://doi.org/10.1104/pp.24.1.1

22. LICHTENTHALLER HK 1987 Chlorophylls and carotenoids, pigments of photosynthetic biomembranes. Method Enzym 148: 350-382. DOI: https://doi.org/10.1016/00766879(87)48036-1

23. BATES L, WALDERN RP, TEARE ID 1973 Rapid determination of free proline for water-stress studies. Plant Soil 39: 205-207. DOI: https://doi.org/10.1007/BF00018060

24. BRADFORD MMA 1976 Rapid sensitive method for the quantitation of micro program quantities of protein utilizing the principle of protein-dye binding. Anal Biochem 72: 248-254. DOI: https://doi.org/10.1006/abio.1976.9999

25. LUTTS S, KINET JM, BOUHARMONT J $1996 \mathrm{NaCl}$-induced senescence in leaves of rice (Oryza sativa L.) cultivars differing in salinity resistance. Ann Bot-London 78: 389- 398. DOI: https://doi.org/10.1006/anbo.1996.0134

26. VELIKOVA V, YORDANOV I, EDRAVA A 2000 Oxidative stress and some antioxidant systems in acid rain-treated bean plants. Plant Sci 151: 59-66. DOI: https://doi.org/10.1016/S01689452(99)00197-1

27. PEARSON D, MELON H, RONALD S 1976 Chemical analysis of food. $8^{\text {th }}$ edition, Churchill Livingstone, pp 5-63. DOI: https:// doi.org/10.4236/jep.2014.513122 3,924

28. SINGLETON VL, ORTHOFER R, LAMUELA-RAVENTÓS RM 1999 Analysis of total phenols and other oxidation substrates and antioxidants by means of Folin-Ciocalteu reagent. Method Enzym 299: 152-178. DOI: https://doi.org/10.1016/S0076$\underline{6879(99) 99017-1}$
29. KUMARAN A, KARUNAKARAN RJ 2006 Antioxidant and free radical scavenging activity of an aqueous extract of Coleus aromaticus. Food Chem 97: 109-114. DOI: https://doi. org/10.1016/i.foodchem.2005.03.032

30. NAKANO Y, ASADA K 1981 Hydrogen peroxide is scavenged by ascorbate-spesific peroxidase in spinach chloroplasts. Plant Cell Physiol 22 (5): 867-880. DOI: https://doi.org/10.1093/ oxfordjournals.pcp.a076232

31. BERGMEYER HU 1975 Methods of Enzymatic Analysis. Academic Press, New York, USA. DOI: https://doi.org/10.1002/ star.19630150713

32. CAKMAK I, MARSCHNER H 1992 Magnesium deficiency and highlight intensity enhance activities of superoxide dismutase, ascorbate peroxidase and glutathione reductase in bean leaves. Plant Physiol 98: 1222-1226. DOI: https://doi.org/10.1104/ pp.98.4.1222

33. ANDERSSON B, BARBER J 1996 Mechanisms of photodamage and protein degradation during photoinhibition of photosystem II. In: Baker NR (eds) Photosynthesis and the Environment. Advances in Photosynthesis and Respiration, vol 5. Springer, Dordrecht. DOI: https://doi.org/10.1007/0306-48135-9 4

34. POORTER H, NIINEMETS U, POORTER L, WRIGHT IJ, VILLAR R 2009 Causes and on sequence of variation in leaf mass per area (LMA): a meta-analysis. New Phytol 182: 565-588. DOI: https:// doi.org/10.1111/i.1469-8137.2009.02830.x

35. ENGLAND JR, ATTIWILL PM 2006 Changes in leaf morphology and anatomy with tree age and height in the broad leaved evergreen species, Eucalyptus regnans F. Muell. Trees 20: 7990. DOI: https://doi.org/10.1007/s00468-005-0015-5

36. HORIE $Y$, ITO $H$, KUSABA M, TANAKA R, TANAKA A 2009 Participation of chlorophyll $b$ reductase in the initial step of the degradation of light harvesting chlorophyll $a / b$-protein complexes in Arabidopsis. J Biol Chem 284: 17449-17456. DOI: https://doi.org/10.1074/ibc.M109.008912

37. SAKURABA $\mathrm{Y}$, TANAKA A, YOKONO M, AKIMOTO $\mathrm{S}$, TANAKA $\mathrm{R}$ 2010 Deregulated Chlorophyll b Synthesis Reduces the Energy Transfer Rate between Photosynthetic Pigments and Induces Photo damage in Arabidopsis thaliana. Plant Cell Physiol 51 (6): 1055-1065. DOI: https://doi.org/10.1093/pcp/pcq050

38. LEMOINE R, LACAMERA $S$, ATANASSOVA R, DÉDALDÉCHAMP F, ALLARIO T, POURTAU N, BONNEMAIN JL, LALOI M, COUTOSTHÉVENOT P, MAUROUSSET L, FAUCHER M, GIROUSSE C, LEMONNIER P, PARRILLA J, DURAND M 2013 Source-to-sink transport of sugar and regulation by environmental factors. Front Plant Sci 4 (272): 1-20. DOI: https://doi.org/10.3389/ fpls.2013.00272

39. DAMESIN C 2003 Respiration and photosynthesis characteristics of current-year stems of Fagus sylvatica: from the seasonal pattern to an annual balance. New Phytol 158: 465-475. DOI: https://doi.org/10.1046/i.1469-8137.2003.00756.x

40. HACKETT WP 1985 Juvenility, maturation and rejuvenation in woody plants. Hort Rev 7: 109-155. DOI: https://doi. org/10.1002/9781118060735.ch3

41. KOUSSEVITZKY S, NOTT A, MOCKLER TC, HONG F, SACHETTOMARTINS G, SURPIN M, LIM IJ, MITTLER R, CHORY J 2007 Signals from chloroplasts converge to regulate nuclear gene expression. Science 316: 715-719. DOI: https://doi. org $/ 10.1126 /$ science. 1140516

42. SZABADOS L, SAVOURE A 2009 Proline: A multifunctional amino acid. Trends Plant Sci 2: 89-97. DOI: https://doi.org/10.1016/i. tplants.2009.11.009

43. STEFFENS B, KOVALEV A, GORB SN, SAUTER M 2012 Emerging roots alter epidermal cell fate through mechanical and reactive oxygen species signalling. Plan Cell 24 (8): 3296-3306. DOI: https://doi.org/10.1105/tpc.112.101790

44. SINHA N 1999 Leaf development in angiosperms. Annu Rev Plant Physiol Plant Mol Biol 50: 419-446. DOI: https://doi. org/10.1146/annurev.arplant.50.1.419 
45. NELSON T, DENGLER N 1997 Leaf vascular pattern formation. The Plant Cell 9: 1121-1135. DOI: https://doi.org/10.1105/ tpc.9.7.1121

46. KNOWLES NR, KNOWLES LO 1990 Changes in fatty acid composition of phospholipids from different ages of potato seed-tubers during sprouting. Ann Bot 65: 217-223. DOI: https://doi.org/10.1093/oxfordjournals.aob.a087927

47. DEHON L, MACHEIX JJ, DURAND M 2002 Involvement of peroxidases in the formation of the brown coloration of heartwood in Juglans nigra. J Exp Bot 53: 303-311. DOI: https:// doi.org/10.1093/jexbot/53.367.303

48. FOYER CH, NOCTOR G 2005 Redox homeostasis and antioxidant signalling: a metabolic interface between stress perception and physiological responses. Plant Cell 17: 1866-1875. DOI: https:// doi.org/10.1105/tpc.105.033589

49. MATTIOLI R, COSTANTINO P, TROVATO M 2009 Proline accumulation in plants-Not only stress. Plant Sig Behav 4 :10161018. DOI: https://doi.org/10.4161/psb.4.11.9797

50. HARBORNE JB 1980 In Secondary plant products. Encyclopaedia of Plant Physiology, Springer-Verlag, Berlin-Heidelberg, pp 329402. DOI: https://doi.org/10.1371/journal.pone.0045345

51. BERNHARDT C, TIERNEY ML 2000 Expression of AtPRP3, a proline-rich structural cell wall protein from Arabidopsis, is regulated by cell-type-specific developmental pathways involved in root hair formation. Plant Physiol 122: 705-714. DOI: https://doi.org/10.1104/pp.122.3.705
52. MALAGUTI D, MILLARD P, WENDLER R, HEPBURN A, TAGLIAVINI M 2001 Translocation of amino acids in the xylem of apple (Malus domestica Borkh.) trees in spring as a consequence of both $\mathrm{N}$ remobilization and root uptake. J Exp Bot 52: 16651671. DOI: https://doi.org/10.1093/jxb/52.361.1665

53. NIINEMETS U 2007 Photosynthesis and resource distribution through plant canopies. Plant Cell Environ 30: 1052-1071. DOI: https://doi.org/10.1111/i.1365-3040.2007.01683.x

54. WOODRUFF DR, BOND BJ, MEINZER FC 2004 Does turgor limit growth in tall trees? Plant Cell Envir 27: 229-236. DOI: https:// doi.org/10.1111/j.1365-3040.2003.01141.x

55. YANG SL, LAN SS, GONG M 2009 Hydrogen peroxide-induced proline and metabolic pathway of its accumulation in maize seedlings. J Plant Physiol 166: 1694-1699. DOI: https://doi. org/10.1016/j.jplph.2009.04.006

56. BENNET N, WALLSGROVE RM 1994 Secondary metabolism in plant defence mechanisms. New Phytol 127: 617-633. DOI: https://doi.org/10.1111/i.1469-8137.1994.tb02968.x

57. ROLLAND F, WINDERICKX J, THEVELEIN JM 2002 Glucosesensing and -signalling mechanisms in yeast. FEMS Yeast Res 2: 183-201. DOI: https://doi.org/10.1128/EC.00028-08

58. LUSK CH, REICH PB 2000 Relationships of dark respiration with light environment and tissue nitrogen content in juveniles of 11 cold-temperate tree species. Oecol 123: 318-329. DOI: https:// doi.org/10.1007/s004420051018 